\title{
Amazonitic alkali feldspar from the Tanakami Granitic pegmatite, southwest Japan
}

\author{
Satoshi NAKANO* and Kuniaki MAKINO ${ }^{* *}$ \\ *Department of Natural Science, Faculty of Education, Shiga University, \\ Hiratsu 2-5-1, Otsu, Shiga 520-0862, Japan \\ ${ }^{* *}$ Department of Geological Sciences, Faculty of Science, Shinshu University, \\ Asahi 3-1-1, Matsumoto, Nagano 390-8621, Japan
}

\begin{abstract}
This is the first detailed description of amazonitic alkali feldspar in Japan. The amazonitic feldspar is from pegmatite in the Tanakami Granite, southwest Japan. Macroscopically, the feldspar is characterized by the coexistence of pale blue and white parts. The two parts of microperthite are distinctly different in terms of their microscopic texture. The pale blue part has clear crosshatched twin patterns, albite laths, and few albite patches with relatively few micropores. In contrast, the white part has unclear twin patterns, few albite laths, and many albite patches with abundant micropores. The pale blue color is due to the host microcline containing $103 \mathrm{ppm}$ of $\mathrm{PbO}$ at the maximum, and the white color is due to both the two albite phases and turbid microcline causing strong diffuse reflection. It is deduced that plagioclase laths were first crystallized and then enclosed by pale blue microcline that crystallized later. Crosshatched twins were formed in the microcline during cooling, and albite replaced the microcline forming perthitic patches with many micropores. The composition of plagioclase laths is very close to that of pure albite, which is same as that of albite patches. The microcline part having undergone extensive albitization appear white to the naked eye; the part that did not undergo albitization has retained its pale blue color. The amazonitic microcline crystallization and albitization are estimated to have occurred at very low temperatures around $200{ }^{\circ} \mathrm{C}$.
\end{abstract}

Keywords: Amazonite, Color, Lead, Water, Hydrothermal, Replacement, Tanakami Granite

\section{INTRODUCTION}

Pegmatite environments are highly variable (Černý, 1993, 1994) and many problems associated with their formation processes still exist (London, 2005). Feldspar microtextures give valuable information on thermal and chemical reactions in various host rocks (Smith and Brown, 1988; Brown and Parsons, 1994; Deer et al., 2001). The evolution of pegmatite feldspars from the crystallization stage to the low-temperature hydrothermal stage has been outlined by Černý et al. (1984) and Černý (1994). Recently, Nakano et al. (2001) and Kohno et al. (2008) clarified the low-temperature multistage events in the formation of pegmatite alkali feldspar that is not amazonite, from their microtextures. However, much more studies on pegmatite feldspars are required to clarify a variety of pegmatite environments and their formation processes.

Amazonites, which are widely known as a blue-

doi:10.2465/jmps.090301

S. Nakano, nakano@edu.shiga-u.ac.jp Corresponding author green variety of alkali feldspar (microcline or orthoclase), mostly occur in pegmatites (Cech et al., 1971; Hofmeister and Rossman, 1983, 1985; Smith and Brown, 1988; Deer et al., 2001). Their colors have been the main subject of many studies to date. The color is considered to be controlled by not only the amount of $\mathrm{Pb}$ but also the amount of water and radioactive irradiation (Hofmeister and Rossman, 1983). However, the characterization of their microtextures has hardly been carried out, except for the study of galena inclusions in the Broken Hill amazonite (Murakami et al., 2000). Several papers on studies on amazonite reported only the existence of microperthites or showed only their photographs without interpretations (Foord and Martin, 1979; Pivec et al., 198 1; Stevenson and Martin, 1986, 1988; Ostrooumov and Banerjee, 2005).

In this study, we characterize microtextures, especially microperthites of Or-rich host and Ab-rich guest phases, of amazonitic alkali feldspar from pegmatite of the Tanakami Granite pluton, Japan, with respect to its 
macroscopic color variation. The sample shows pale blue and white parts. The former part is amazonite, but the latter is not amazonite; however, alkali feldspar is recognized to be amazonitic as a whole in this study. The term "amazonitic" was first used for amazonite coexisting with white alkali feldspar by Stevenson and Martin (1988). This term is now used in a broad sense for blue-green colored alkali feldspars, regardless of paragenesis and texture (Martin et al., 2008). The occurrence of amazonites or amazonitic alkali feldspars in Japan has been reported (Nagashima et al., 1975; Kobayashi, 1989; Matsubara, 2003; etc.); however, this is the first time that their detailed description is being reported. This paper should provide new insight into amazonitic alkali feldspars.

\section{GEOLOGICAL BACKGROUND AND EXAMINED SAMPLE}

Many Cretaceous granitic plutons are widely distributed in the inner zone of southwest Japan. Several granite plutons among them are distributed around Lake Biwa, the biggest lake in Japan. The Tanakami Granite pluton of dimensions ca. $15 \mathrm{~km} \times 20 \mathrm{~km}$ is situated to the southeast of Lake Biwa (Collaborative Research Group for the Granites around Lake Biwa, 2000; Nakano and Harayama, 2003). It belongs to the ilmenite-series granites (Ishihara, 1977). Ishihara et al. (2005) reported that the Tanakami Granite is rich in radioactive elements such as $\mathrm{U}$ (3.1-6 ppm) and Th (18-30 ppm) as well as F (max. $1550 \mathrm{ppm})$ and rare-earth elements (179-290 ppm) as compared to other Japanese granites.

There are many pegmatite cavities in the western margin of the Tanakami Granite pluton (Tsuji and Kitahara, 1979). The Tanakami pegmatite is famous for large and beautiful topaz (Dana and Ford, 1959), beryl, and zinnwaldite crystals. Many beautiful smoky and black rock crystals are found to exist along with abundant feldspar crystals as major minerals. Alkali feldspars are generally reddish, and plagioclases (albite) are generally white. In addition, around 40 minerals have been reported to be obtained from the pegmatites (Tsuji and Kitahara, 1979), for example, euxenite, yttrotantalite, fergusonite, samarskite, columbite, cassiterite, fluorite, gadolinite, zircon, and garnet.

Amazonitic alkali feldspars occur in the Tanakami pegmatite. The present sample is the largest one among them, with dimensions of approximately $3 \mathrm{~cm} \times 2 \mathrm{~cm} \times 5$ $\mathrm{cm}$. Macroscopically, this sample shows a combination of white and pale blue parts. To our regret, however, its precise locality and occurrence are unknown, because late Mrs. Kobayashi found it more than 40 years ago in the western margin of the Tanakami Granite pluton (around $\left.135^{\circ} 58^{\prime} \mathrm{E}, 34^{\circ} 56^{\prime} \mathrm{N}\right)$, Otsu City, Shiga Prefecture.

\section{ANALYTICAL METHODS}

A BRC112E spectrometer (B\&W Tek, Inc., USA) was used for color measurement. The naturally plain (110) surface of the sample was illuminated vertically by incandescent electric light (Fig.1). The scattered light was detected at a catch angle of $45^{\circ}$ by the acceptor of diameter $0.1 \mathrm{~mm}$ that was attached to the CCD detector body. The intensity of scattered light for different wavelengths (0.6-nm step in the range of 400-800 nm) was recorded by using the BWSpec 3.23 software installed in a connected PC. The data were calibrated by taking into account several factors such as dark compensation for the CCD detector and reference data of source light.

Thin sections of the sample were examined under an optical microscope and by using a JEOL JXA $8800 \mathrm{M}$ electron probe microanalyzer (EPMA) at Shiga University. The analytical conditions were as follows: accelerating voltage $=15 \mathrm{kV}$, probe current $=0.05 \mu \mathrm{A}$ (mapping) and $0.02 \mu \mathrm{A}$ (quantitative analyses), and the beam was focused for mapping and defocused to diameters of $5 \mu \mathrm{m}$ for phase compositions and $50 \mu \mathrm{m}$ for local bulk compositions). The mapping was carried out using a stage scan under the following settings: resolution $=500 \times 500$ pixels and dwell time $=180-200 \mathrm{~ms}$. Quantitative analyses of major elements were carried out by using Bence and Albee's procedure (1968), which is as follows. The bulk composition of the feldspar sample was estimated by averaging the local-bulk composition $(\mathrm{n}=435)$. The $\mathrm{Pb}$ concentration was determined by using a synthetic glass standard (55.62 wt\% $\mathrm{PbO}$ ) under the following conditions: peak counting time $=500 \mathrm{~s}$, background counting time $=500 \mathrm{~s}$, and probe current $=0.05 \mu \mathrm{A}$.

The sample was also investigated by FT-IR and XRD analyses. The FT-IR analysis was carried out using a Janssen MFT-2000 spectrometer at Shinshu University. The analytical conditions were the same as those in a previous study (Nakano et al., 2001), and the beam diameter was $100 \mu \mathrm{m}$. The XRD analyses were carried out to determine the feldspar obliquity (Goldsmith and Laves, 1954) by using a Rigaku X-ray diffractometer at Shiga University. The operating conditions were $35 \mathrm{kV}, 15 \mathrm{~mA}$, and a scan speed of $0.5^{\circ}$ per minute.

\section{FELDSPAR COLORS DETECTABLE TO THE NAKED EYE}

The feldspar shows several well-developed facets (Fig. 1). The development of the (110) facet is characteristic (Fig. 1), probably comparable to the adularia habit (Černý and 


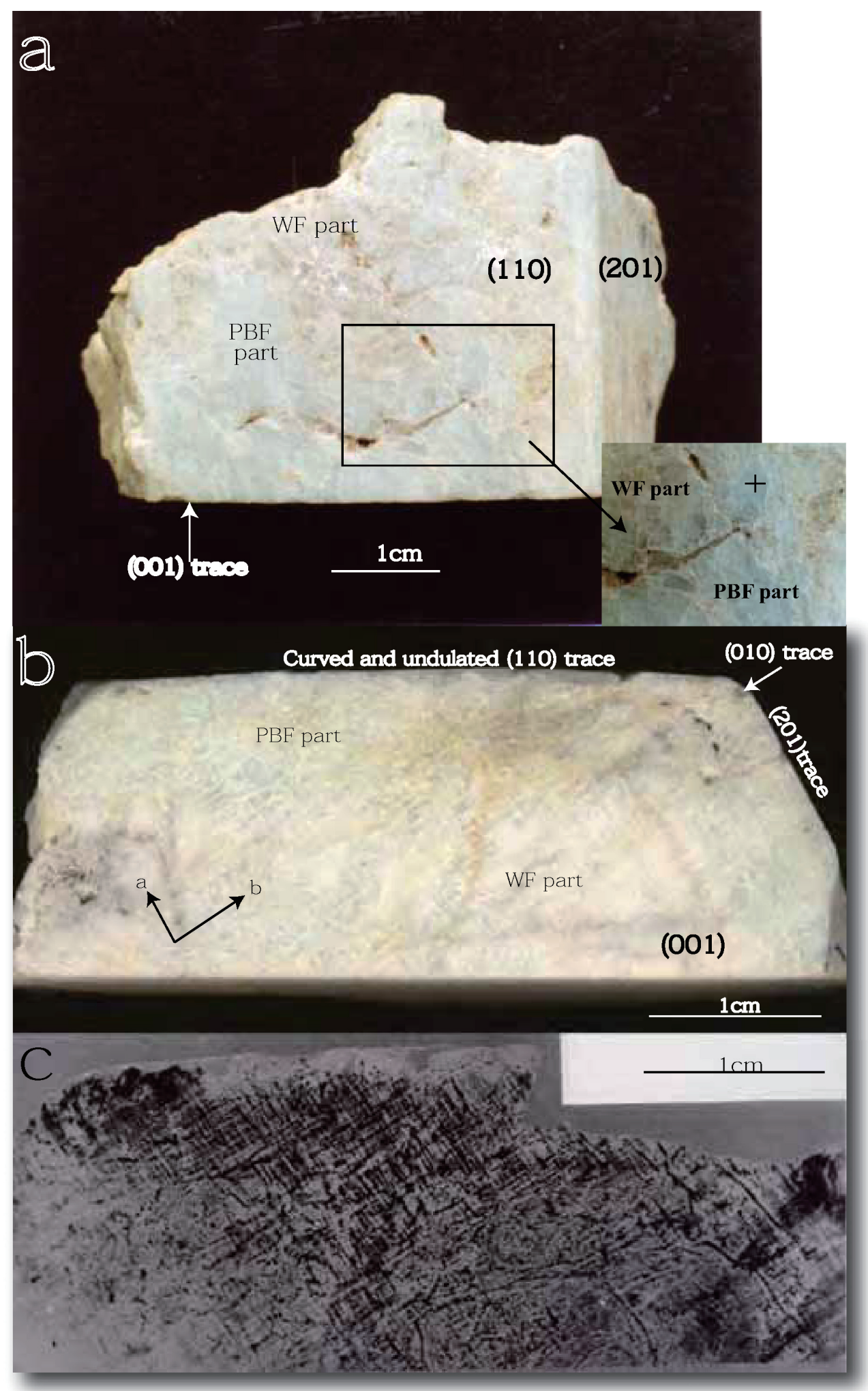

Figure 1. Photographs of amazonitic alkali feldspar from the Tanakami pegmatite. (a) Feldspar grain consisting of pale blue feldspar (PBF) part and white feldspar (WF) part. The inset shows a close-up of the rectangular part. The cross in the inset shows the position for which the color data are shown in Figure 2. (b) Complex color combination of PBF and WF parts on (001) section, which was cut from grain shown in (a). (c) Textural contrast between PBF and WF parts under crossed polarizers on (001) section obtained from chip shown in (b). Crosshatched twin patterns are clear in the PBF part, but almost absent in the WF part. Perthitic textures of the Or-rich host and Ab patches are present in the WF part. 


\section{a}

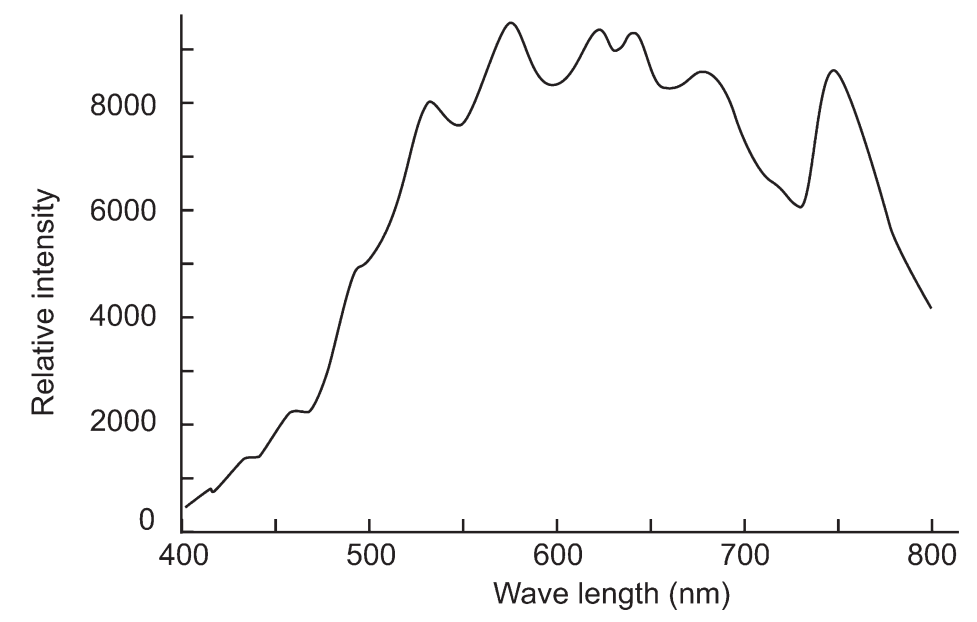

b

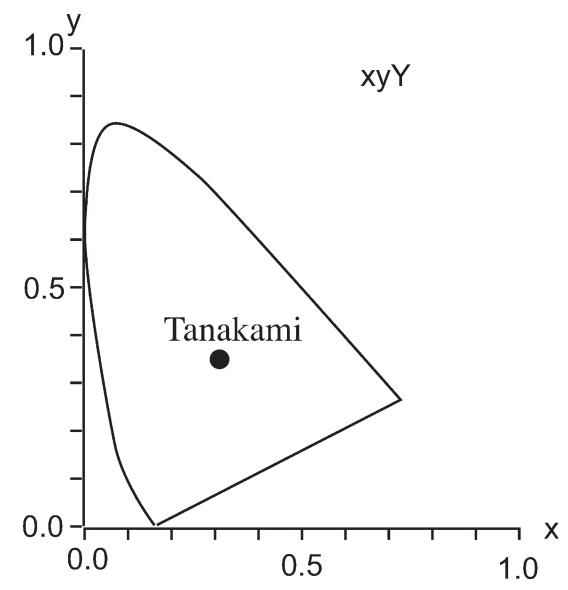

c

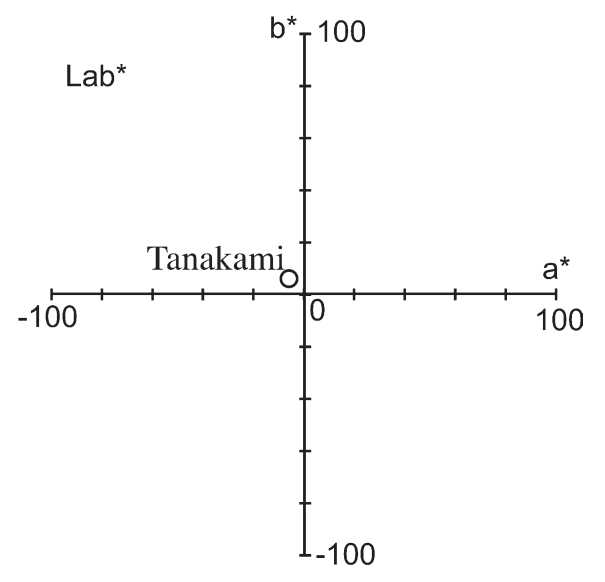

Figure 2. Color characterization of amazonitic alkali feldspar from the Tanakami Granite. (a) Typical spectral pattern of PBF obtained by using BRC112E spectrometer for the position shown in Figure 1a. (b) $\mathrm{a}^{*}$ $\mathrm{b}^{*}$ plot on the $\mathrm{L}^{*} \mathrm{a}^{*} \mathrm{~b}^{*}$ color coordinate system, obtained from data shown in (a). (c) Corresponding $x^{-} y$ plot on the xyz color coordinate system.
Chapman, 1984). It is notable that the present crystal facets are undulated, with small pits and grooves at some places.

The feldspar consists of two parts that appear pale blue (hereafter referred to as PBF) and white (hereafter referred to as WF) in color to the naked eye (Figs. 1a and 1b). The former part is translucent, but the latter is opaque. Close inspections with the naked eye reveal the combination of PBF and WF to be complex (Figs. 1a and 1b). The WF part in the PBF part appears in the form of small veins, bands, patches, or domains. The PBF part in the WF part is enclosed as irregular domains of various sizes. Texturally, it appears that the WF part projects into and/or encloses the PBF part.

Spectral patterns and corresponding digital data of colors obtained from different positions are nearly the same for any examined area of the (110) facet. A typical spectral pattern is shown in Figure 2. The digital data were converted to parameters of the $\mathrm{L}^{*} \mathrm{a}^{*} \mathrm{~b}^{*}$ color coordinate system and the xyz color coordinate system as the international color coordinate systems, using the software supplied with the present spectrometer. The obtained color data are $\mathrm{L}^{*}=82.61, \mathrm{a}^{*}=-5.77$, and $\mathrm{b}^{*}=6.41$, where $\mathrm{L}^{*}$ indicates the brightness value and $\mathrm{a}^{*}$ and $\mathrm{b}^{*}$ indicate hues. The negative value of $\mathrm{a}^{*}$ indicates a green tint, and the positive value of $b^{*}$ indicates a yellow tint. The two parameters combined together show a pale (grey) yellowgreen tint (Fig. 2b). In Figure 2c, the parameters $\mathrm{x}=$ 0.3164 and $y=0.3472(\mathrm{z}=0.3364)$ are plotted in the region of a bright (white) yellow-green tint.

\section{FELDSPAR MICROTEXTURES}

The two parts of the feldspar are macroscopically different in color and have distinct microtextures, especially the (001) section (Figs. 1c, 3, and 4), although they are patch 


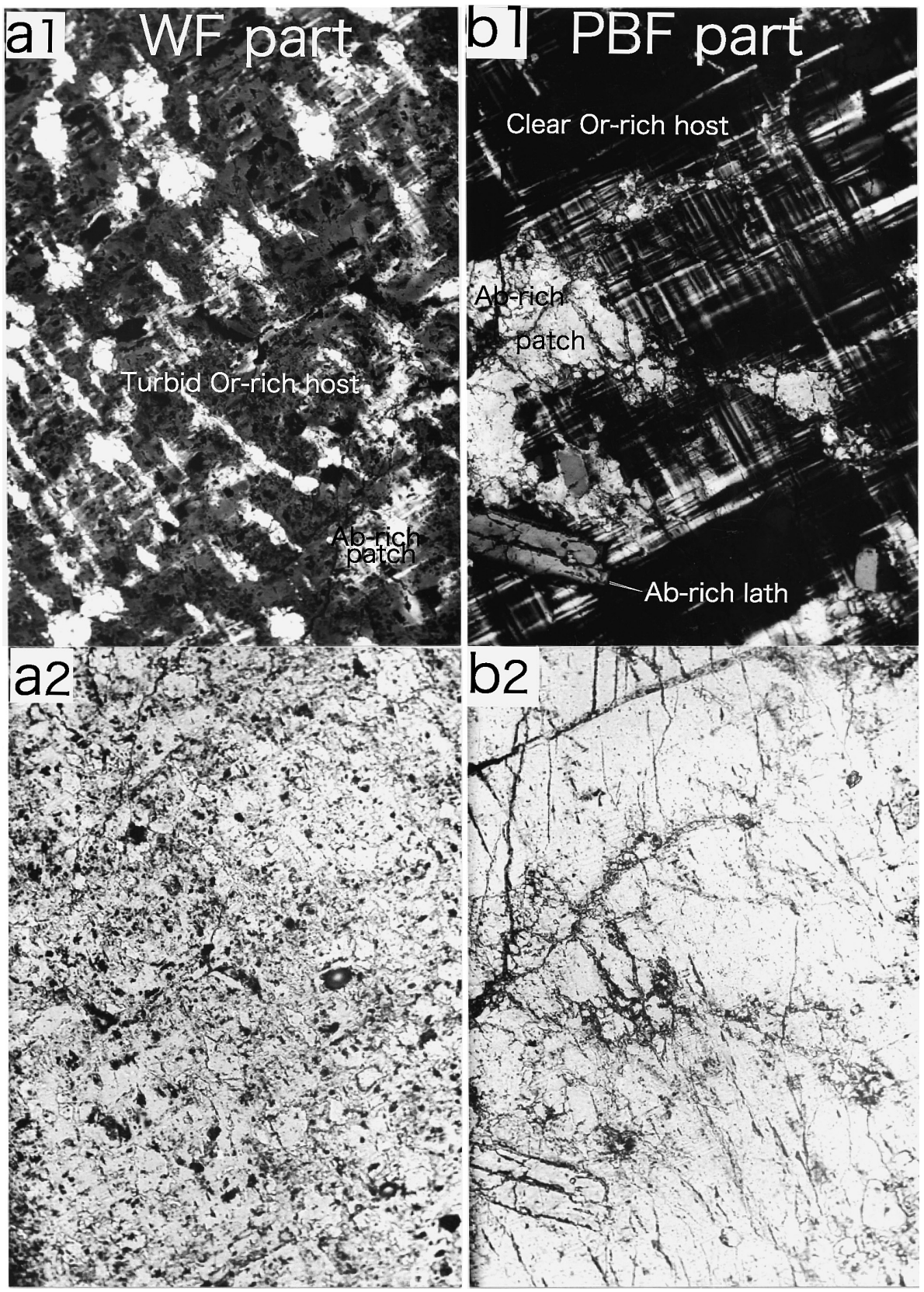

Figure 3. Microphotographs showing distinct textures of (a) WF and (b) PBF parts: (a1) and (b1) with one polarizer and (a2) and (b2) with crossed polarizers. The WF part is highly turbid due to the presence of many micropores and minute alteration materials in the well-developed perthitic texture. The PBF part is rather clear and shows two types (fine and coarse) of crosshatched twin patterns.

microperthites of an Or-rich host and an Ab-rich guest. Figure 1c shows their textural differences on a macroscopic scale, and Figures 3 and 4 show the differences on a microscopic scale.

$\mathrm{Ab}$-rich laths and $\mathrm{Ab}$-rich patches are scattered in the PBF part. However, the latter occur in considerably lesser quantities in the PBF part than in the WF part. The $\mathrm{PBF}$ part is relatively clear due to a small quantity of micropores that are developed in and around the $\mathrm{Ab}$-rich patches (Fig. 4). These patches have the same crystallographic orientation over the grains. On the other hand, the $\mathrm{Ab}$-rich laths of variable sizes are scattered with different orientations, both elongation and optical orientations. In addition, crosshatched twins are distinctly formed in the PBF part. Fine and coarse crosshatched twin patterns are recognized in the Or-rich host (Fig. 3). The former is a combination of albite and pericline polysynthetic twins of 2-20 $\mu \mathrm{m}$ in width. These fine-scale twins are formed as broad bands of several hundred micrometers in width along the $b$-axis at intervals of several hundred micrometers. The crosshatched twin pattern corresponds to the crosshatched pattern shown in Figure 1.

Many Ab-rich patches of various sizes are distributed in the WF part, but Ab-rich laths are almost absent in this part. The WF part is turbid due to a large number of micropores in and around the $\mathrm{Ab}$ patches. Furthermore, 


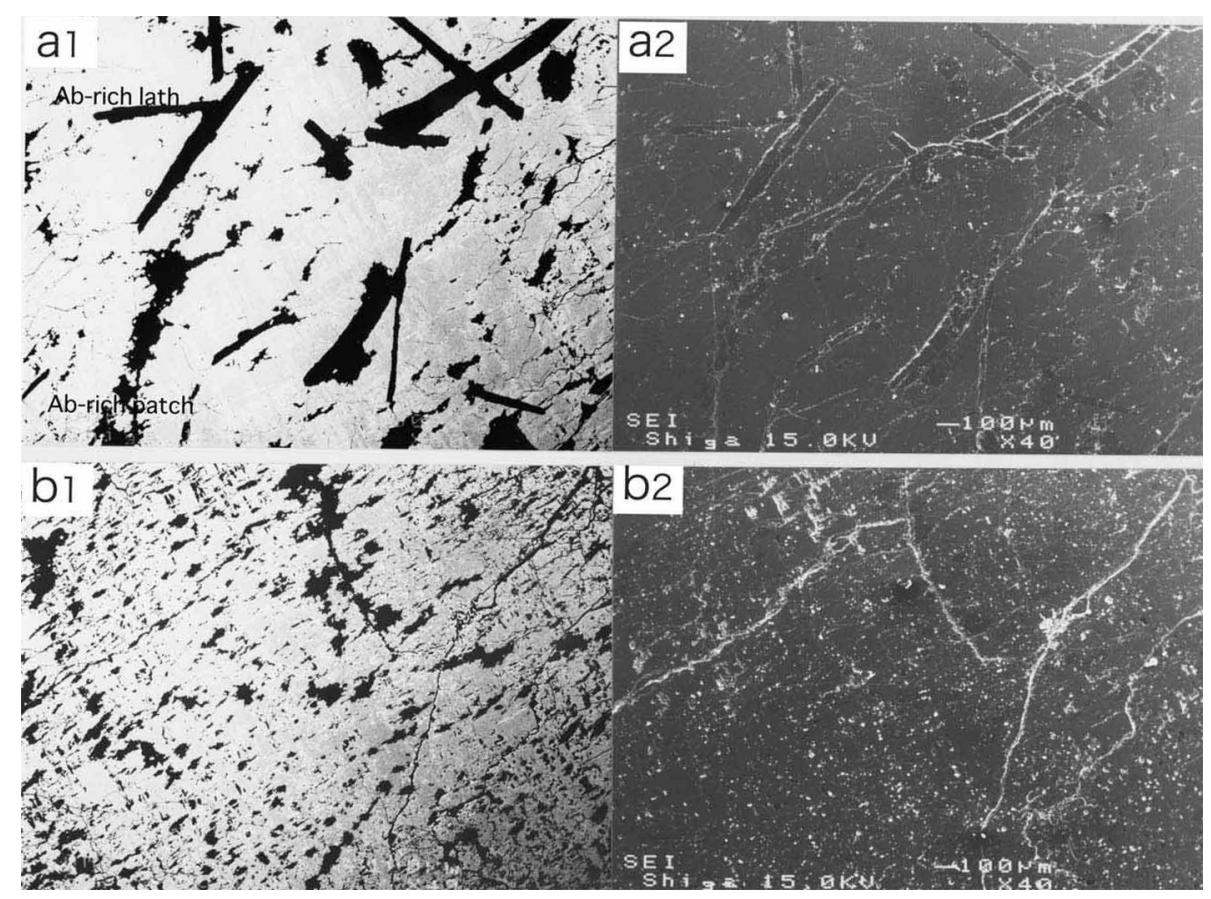

Figure 4. (a1) and (b1) Backscattered electron images (BEIs) and (a2) and (b2) secondary electron images (SEIs) images of PBF and WF parts of the present amazonitic feldspar. $\mathrm{Ab}$-rich patches are very weakly aligned in the PBF part. The Abrich patches are aligned along the $\boldsymbol{b}$ - and $\boldsymbol{a}$-axes in the WF part.

the $\mathrm{Ab}$ patches tend to be aligned roughly along the $\mathrm{a}^{-}$ and $\mathrm{b}$-axes in the WF part, especially in the boundary areas with the PBF part. It is notable that many grains of alteration materials are present in some regions in the WF part (Fig. 3). These materials have not been identified, although muscovite flakes and many opaque particles are found to be scattered. The crosshatched twin patterns in the WF part become very blurred or disappear, which may have been caused by the formation of many Ab-rich patches and the presence of micropores and alteration materials.

\section{ELEMENT DISTRIBUTIONS}

Distribution patterns of $\mathrm{Na}, \mathrm{K}$, and Ca obtained by EPMA mapping clearly resolved the textural difference between the PBF and WF parts (Figs. 5 and 6). Moreover, they revealed the characteristic feature of their distributions: there are minor compositional fluctuations in the both Orrich host and $\mathrm{Ab}$-rich guest phases (patches and laths) (Fig. 5). However, some compositional contrast is recognized in the Or-rich host of the WF part (Fig. 6). Halolike regions depleted in $\mathrm{Ab}$ components appear to develop around the Ab-rich patches. The Ab-rich patches and laths are completely depleted in Ca over the grains (Figs. 5 and 6) as compared to other pegmatite alkali feldspars from Japan (Nakano, 1997; Kohno et al., 2008).

From $\mathrm{Pb}$ mapping of the PBF and WF parts, it is clear that the Or-rich host is relatively rich in $\mathrm{Pb}$, but the $\mathrm{Ab}$-rich patches or laths are depleted in $\mathrm{Pb}$ (Figs. 5 and 6).
The average $\mathrm{Pb}$ content of the mapping regions appears to be consistent with the proportion of the Or-rich phase to the Ab-rich phase in the examined alkali feldspar.

\section{COMPOSITIONAL FEATURES}

The bulk composition is found to be $\mathrm{Or}_{77} \mathrm{Ab}_{23} \mathrm{An}_{0.035}(\mathrm{n}=$ 435), which was obtained by the so-called traverse method using a $50-\mu \mathrm{m}$ electron beam. The local bulk composition fluctuates from $\mathrm{Or}_{60}$ to $\mathrm{Or}_{88}$.

Selected phase compositions are listed in Table 1. The compositions of $\mathrm{Ab}$-rich patches and laths are very close to those of the end member; the $\mathrm{Ab}$-rich patches and laths are found to be depleted in $\mathrm{Ca}$ as already mentioned. Therefore, these are hereafter referred to as $\mathrm{Ab}$ patches and $\mathrm{Ab}$ laths, respectively. The composition of the Or-rich host is also close to that of the end member. The Or-rich host is predominantly consists of $\mathrm{Or}_{98}$ and subordinately of the Or-poor compositions $\mathrm{Or}_{92-96}$. The compositional range $\left(\mathrm{Or}_{92-98}\right)$ of the host is much narrower than that of other Tanakami samples $\left(\mathrm{Or}_{84-98}\right)$ (Kohno et al., 2008) and Nango and Ishikawa samples $\left(\mathrm{Or}_{73-98}\right)$ (Nakano, 1997).

The Or-rich host has a small amount of $\mathrm{Pb}$, and the $\mathrm{Ab}$ phases (both laths and patches) are depleted in $\mathrm{Pb}$ (Fig. 5). The maximum $\mathrm{PbO}$ content of the Or-rich host is $103 \mathrm{ppm}(\mathrm{Pb}=96 \mathrm{ppm})$, and the average $\mathrm{PbO}$ content is $68 \mathrm{ppm}(\mathrm{Pb}=63 \mathrm{ppm})$. The $\mathrm{PbO}$ content of the $\mathrm{Ab}$ patches and laths is below the detection limit (54 ppm). 

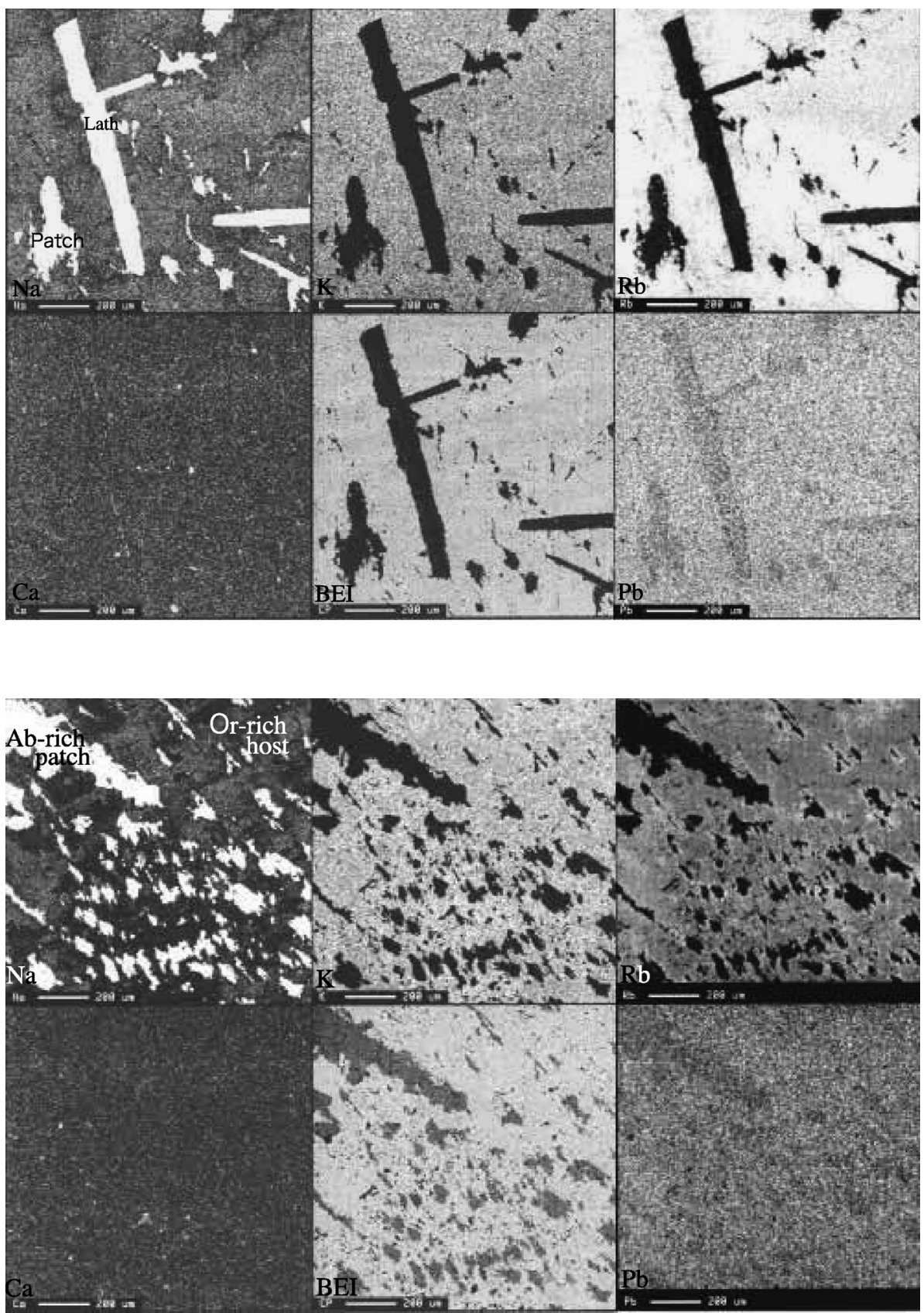

Figure 5. Element distribution maps and textural image for PBF part, obtained by EPMA. It is notable that compositional fluctuations are very small in both the Or-rich host and the $\mathrm{Ab}$-rich laths and patches. $\mathrm{Ca}$ is almost absent in the Or-rich host and $\mathrm{Ab}$-rich laths and patches. The $\mathrm{Pb}$ content of the Ab-rich phases is the same as the background level. The scale bars are $200 \mu \mathrm{m}$.
Figure 6. Element distribution maps and textural image for WF part, obtained by EPMA. There is some compositional fluctuation in the $\mathrm{Or}-$ rich host and very small fluctuations in the Ab-rich patches. $\mathrm{Ca}$ is almost absent in the PBF part. The $\mathrm{Pb}$ content of the $\mathrm{Ab}$-rich phases is the same as the background level. The scale bars are $200 \mu \mathrm{m}$.

\section{WATER ALLOCATION}

Absorption spectra of the feldspar were measured with unpolarized IR light to examine water allocation (Nakano et al., 2001). The FT-IR spectra of the PBF and WF parts recorded between $3000 \mathrm{~cm}^{-1}$ and $4000 \mathrm{~cm}^{-1}$ (Fig. 7) are very similar to those of both the clear featureless and turbid microperthitic parts in the alkali feldspar from the Hanazono Pegmatite examined by Nakano et al. (2001). The spectra could be separated into three bands with peaks around 3250,3450 , and $3600 \mathrm{~cm}^{-1}$, according to the procedure described by Nakano et al. (2001). By compari- son with the case of the Hanazono alkali feldspar (Nakano et al., 2001), from the textural and spectral similarities of the two samples, it can be estimated that a small amount of structural water (around $3600 \mathrm{~cm}^{-1}$ ) and additional molecule water (around 3250 and $3450 \mathrm{~cm}^{-1}$ ) are trapped in both the Or-rich host feldspars. The WF part contains a larger amount of water than the PBF part.

\section{Si-AI ORDERING}

The PBF and WF parts were examined by using the Rigaku X-ray powder diffractometer at Shiga University. 
Table 1. Representative chemical composition of the Tanakami amazonitic alkali feldspar

\begin{tabular}{|c|c|c|c|c|c|c|}
\hline \multirow[b]{3}{*}{$\mathrm{SiO}_{2}$} & \multicolumn{2}{|c|}{ Or-rich host } & \multicolumn{2}{|c|}{ Ab-patch } & \multicolumn{2}{|c|}{ Ab-lath } \\
\hline & \multicolumn{6}{|c|}{ Oxide compositions (wt\%) } \\
\hline & 64.1 & 64.3 & 68.5 & 68.3 & 68.0 & 68.1 \\
\hline $\mathrm{Al}_{2} \mathrm{O}_{3}$ & 18.4 & 18.4 & 20.0 & 19.9 & 19.3 & 19.9 \\
\hline $\mathrm{FeO}$ & 0.00 & 0.01 & 0.00 & 0.00 & 0.03 & 0.02 \\
\hline $\mathrm{CaO}$ & 0.00 & 0.00 & 0.01 & 0.00 & 0.00 & 0.01 \\
\hline $\mathrm{Na}_{2} \mathrm{O}$ & 0.66 & 0.44 & 11.9 & 11.4 & 11.6 & 11.8 \\
\hline $\mathrm{K}_{2} \mathrm{O}$ & 15.7 & 16.3 & 0.12 & 0.13 & 0.15 & 0.10 \\
\hline $\mathrm{BaO}$ & 0.13 & 0.02 & 0.01 & 0.06 & 0.04 & 0.00 \\
\hline \multirow[t]{2}{*}{ Total } & 99.0 & 99.5 & 100.5 & 99.8 & 99.1 & 99.9 \\
\hline & \multicolumn{6}{|c|}{ Atomic proportions $(0=8)$} \\
\hline $\mathrm{Si}$ & 2.989 & 2.992 & 2.978 & 2.985 & 2.998 & 2.977 \\
\hline $\mathrm{Al}$ & 1.014 & 1.008 & 1.026 & 1.027 & 1.000 & 1.027 \\
\hline $\mathrm{Fe}$ & 0.000 & 0.000 & 0.000 & 0.000 & 0.001 & 0.001 \\
\hline $\mathrm{Ca}$ & 0.000 & 0.000 & 0.001 & 0.000 & 0.000 & 0.001 \\
\hline $\mathrm{Na}$ & 0.059 & 0.040 & 1.001 & 0.969 & 0.995 & 1.004 \\
\hline $\mathrm{K}$ & 0.935 & 0.969 & 0.007 & 0.007 & 0.009 & 0.005 \\
\hline $\mathrm{Ba}$ & 0.002 & 0.000 & 0.000 & 0.001 & 0.001 & 0.000 \\
\hline Total & 4.999 & 5.009 & 5.013 & 4.989 & 5.004 & 5.015 \\
\hline \multicolumn{7}{|c|}{ Or-Ab-An ternary feldspar compositions (mol\%) } \\
\hline An & 0.0 & 0.0 & 0.0 & 0.0 & 0.0 & 0.1 \\
\hline $\mathrm{Ab}$ & 6.0 & 4.0 & 99.3 & 99.2 & 99.2 & 99.4 \\
\hline Or & 94.0 & 96.0 & 0.7 & 0.8 & 0.8 & 0.5 \\
\hline
\end{tabular}
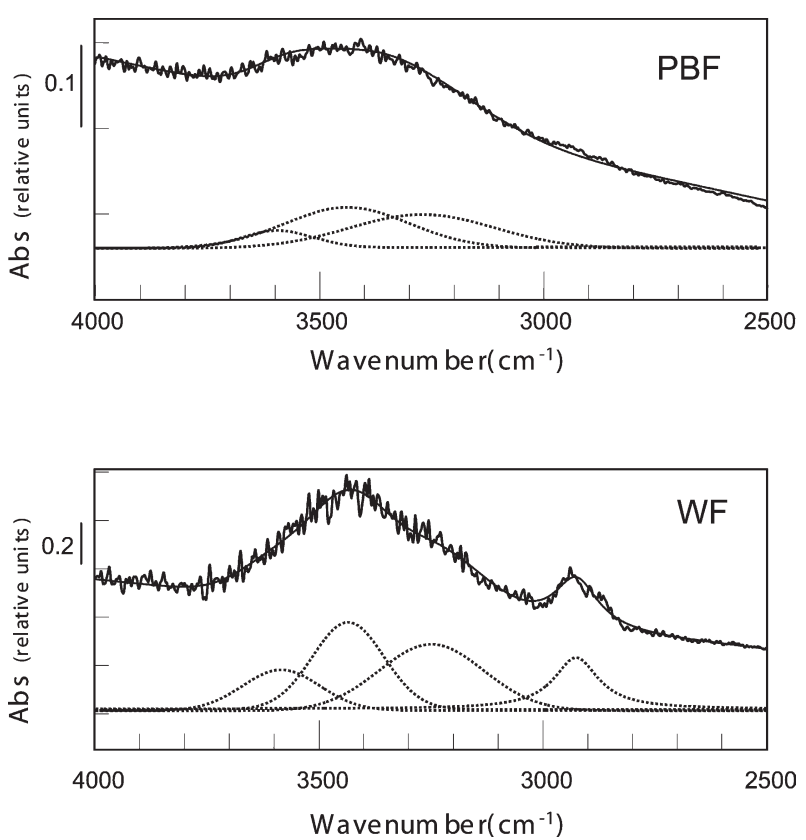

Figure 7. Micro FT-IR spectra for Or-rich hosts of (a) PBF and (b) WF parts. Peak separation was carried out by using the method described by Nakano et al. (2001).

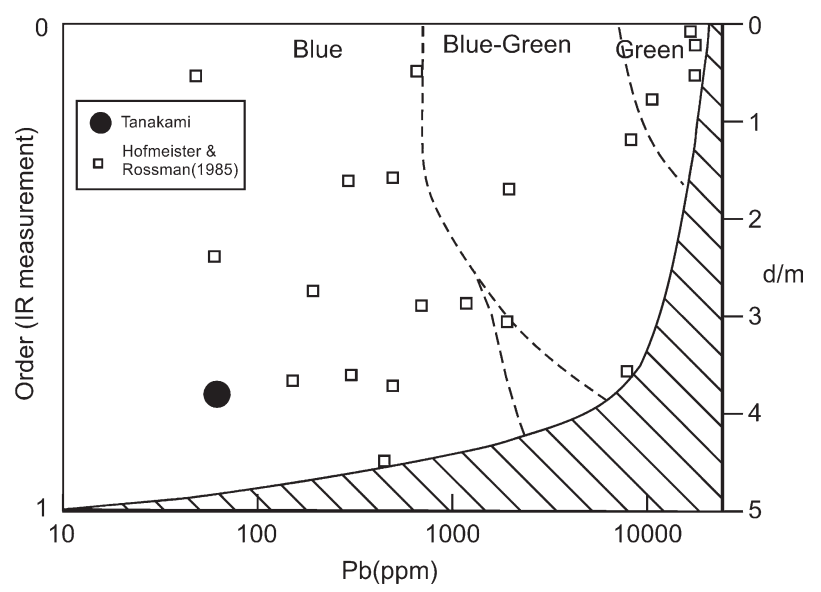

Figure 8. Plot of $\mathrm{Pb}$ content against order parameters showing color variation in amazonites, which was proposed by Hofmeister and Rossman (1985). Feldspar obliquity is used for the present pale blue microcline, instead of the original order parameter obtained from IR data. The average $\mathrm{Pb}$ content $(63 \mathrm{ppm})$ is used for the microcline.

It was confirmed that the feldspars in both the PBF and WF parts consist mainly of microcline and albite, although the feldspars appear different in terms of their microtextures. The feldspar obliquity (Goldsmith and Laves, 1954) of the microcline was found to be 0.79 and 0.75 in the PBF part and in the WF part, respectively.

\section{DISCUSSION}

\section{Reason behind color variation in feldspar}

Hofmeister and Rossman (1985) have clarified that for alkali feldspars to have a blue-green color, not only an appropriate amount of $\mathrm{Pb}$ content but also a certain level of irradiation and some amount of water are required. They pointed out that lead and water occur in a 1:1 ratio at the color center and water plays a catalytic role in the irradiative transfer of $\mathrm{Pb}^{2+}$ to the amazonite chromophore $\left(\mathrm{Pb}^{3+}\right)$. As a result, the presence of a small amount of $\mathrm{Pb}$ (in ppm) leads to the pale blue color of the alkali feldspar. They found that the minimum $\mathrm{Pb}$ content required for this color is approximately $60 \mathrm{ppm}$. An increase in the $\mathrm{Pb}$ content of amazonites changes their colors from blue to green through blue-green color.

Foord and Martin (1979) studied the occurrence of amazonites at Pikes Peak, Colorado, USA, and reported the overgrowth of white-colored feldspars on the amazonites. Stevenson and Martin (1986) reported the coexistence of amazonitic and white alkali feldspars in the same pegmatite or in the same grain from the Geco pegmatites of Canada, as follows. "There are also individual grains of amazonite that vary in color from white to green. This 
zonation is never concentric, but up to half the crystal may be green and may grade to white in the other half. In a few cases, the amazonite is mottled green and white." On the basis of some overlaps in the variation range of the $\mathrm{Pb}$ content of amazonites and non-amazonites, they suggested that the lack of color could stem either from insufficient or excess natural irradiation or from the lack of $\mathrm{Pb}^{-}$ $\mathrm{H}_{2} \mathrm{O}$ pairs. They could not explain the coexistence of these two feldspars. Stevenson and Martin (1988) studied alkali feldspars in the Portman Lake granodiorite (not pegmatite) and reported that the $\mathrm{Pb}$ content of the amazonite exceeds $14,800 \mathrm{ppm}$ and that in the coexisting white feldspar is less than $300 \mathrm{ppm}$ as a rule.

The present host microcline (obliquity $=0.75-0.79$ ) contains a small amount of $\mathrm{Pb}$ (63 ppm on an average) regardless of its occurrence. The microcline in the PBF part contains a trace amount of structural water (Fig. 7). In addition, the Tanakami Granite is rich in radioactive elements (Ishihara et al., 2005), as collaborated by the common occurrence of smoky or black quartz in the pegmatite cavities. These two observations are sufficient evidence for attributing the pale blue color to the clear host microcline. The pale blue color of the microcline is characterized, as shown in Figure 8, on the basis of the figure presented by Hofmeister and Rossman (1985), although the methods used by them for measuring the obliquity of alkali feldspars was different. Hofmeister and Rossman (1986) also considered the same mechanism for blue coloring of plagioclase. However, the present two types of $\mathrm{Ab}$ phases are too low in $\mathrm{Pb}$ to contribute to pale-blue coloring.

On the basis of the above conclusions, the macroscopic color variation from the PBF part to the WF part is interpreted as follows. Many micropores along with minute alteration materials are scattered through out both the microcline and $\mathrm{Ab}$ patches in the turbid patch microperthite (WF). As a result, macroscopically, the pale blue color is completely lost in the turbid microperthitic part. The presence of a large number of micropores (or microinclusions such as fluid inclusions) in microperthites causes strong diffuse reflection that leads to microscopic turbidity and macroscopic whiteness (Worden et al., 1990; Walker et al., 1995). A close inspection reveals complex blending patterns of pale blue and white colors in the sample, which are like irregular veins, patches, and domains (Figs. 1a and 1b). These patterns correspond fundamentally to the distribution patterns of microperthitic $\mathrm{Ab}$ patches observed under a microscope (Figs. 1c, 3, and 4). It is concluded that the distribution of $\mathrm{Ab}$ components controls the macroscopic color variation from pale blue to white in the feldspar.

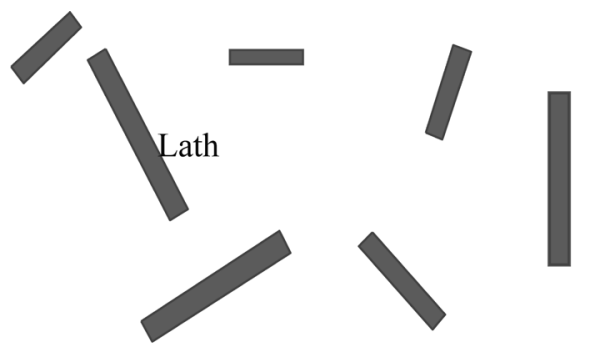

Stage I: crystallization of Ab-rich laths

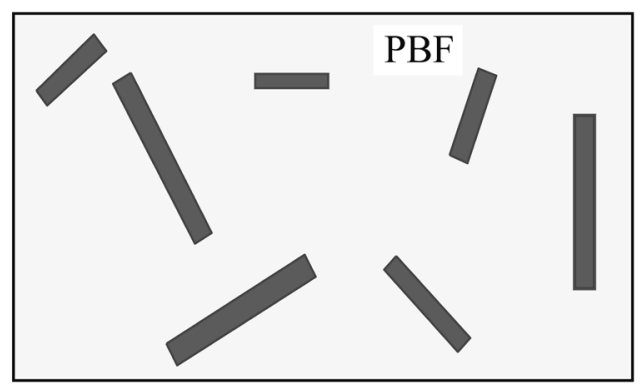

Stage II: crystallization of Or-rich feldspar

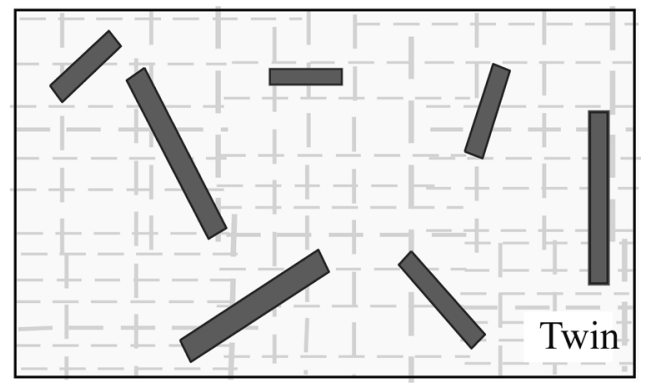

Stage III: genesis of transition twin

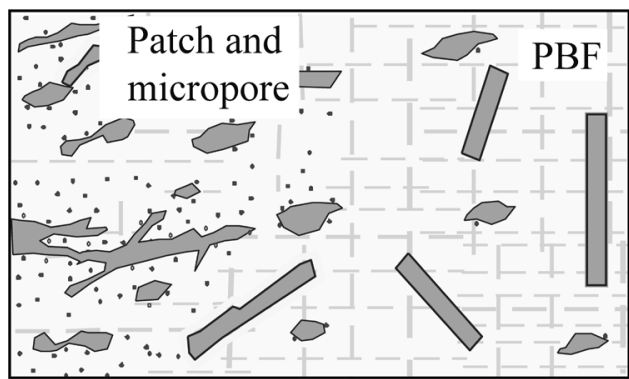

Stage IV: replacement forming Ab-rich patches

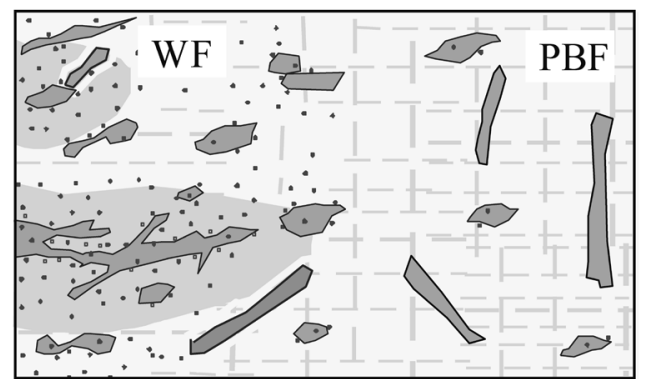

Stage V: further alteration increasing turbidity

Figure 9. Schematic model for microtextural formation of the Tanakami amazonitic alkali feldspar. 


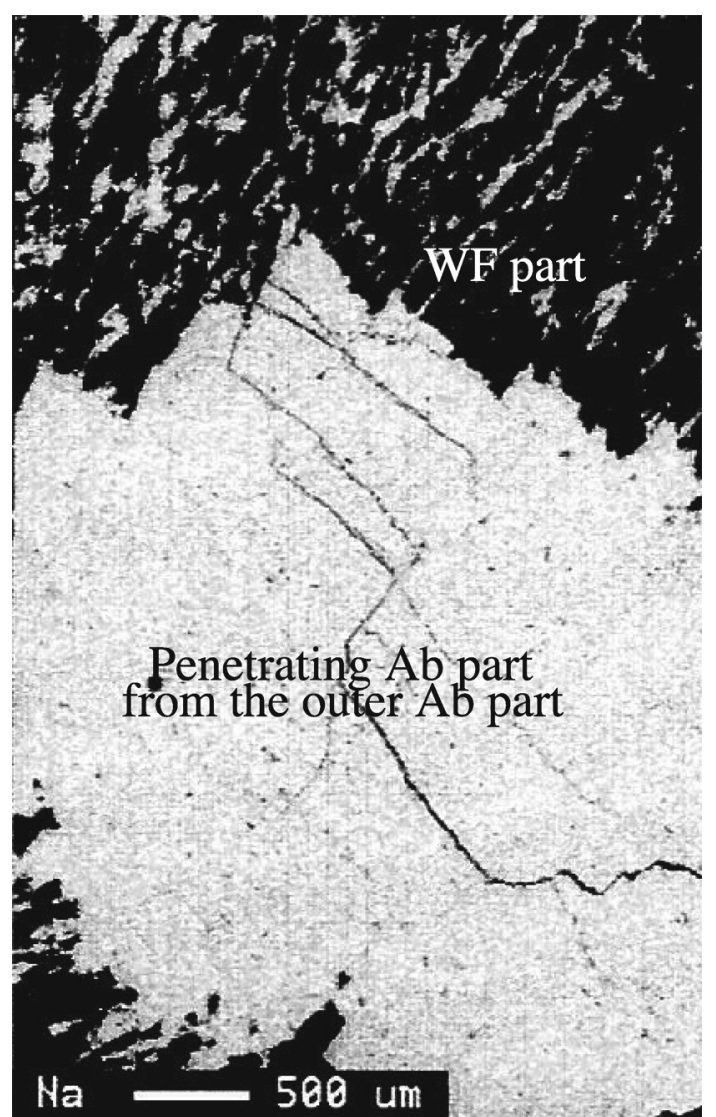

Figure 10. Na distribution map of large albite grain connected to albite veins or patches in WF part, forming perthitic texture. This map corresponds to the lower left end of the feldspar shown in Figures $1 \mathrm{~b}$ and $1 \mathrm{c}$.

\section{Textural evolution during cooling}

Černý et al. (1984) clarified the compositional variation in alkali feldspars in magmatic rocks to low-temperature hydrothermal stages within a pegmatite from Vezna. Further, Černý (1994) summarized that the perthite evolution of pegmatite alkali feldspars takes place by exsolution, coarsening, and recrystallization. Many recent studies on microtextures of alkali feldspars from syenites (Parsons, 1978; Parsons and Brown, 1984; Brown and Parsons, 1994; Nakano et al., 2005; etc.) and granites (Lee et al., 1995; Lee and Parsons, 1997; Hashimoto et al., 2005) have shown that patch microperthites are formed along with many micropores by hydrothermal coarsening leading to microscopic turbidity. Černý (1994) also pointed out that the coarsening and segregation of perthite components proceed much farther in pegmatites than in any other geological environment.

The PBF part, which includes many Ab laths and is associated with distinct crosshatched twin patterns, has a small number of $\mathrm{Ab}$ patches and micropores; hence, it is clear microscopically. The WF part is texturally different from the PBF part. Crosshatched twin patterns are not clear in the former. Although the WF part has only a few $\mathrm{Ab}$ laths, it has many $\mathrm{Ab}$ patches with a large number of micropores; hence, it is turbid microscopically. The formation of these textural contrasts can be explained by the following scenario (Fig. 9).

The laths must have been first formed in the pegmatite melt or fluid (stage I), because they are randomly scattered with not only elongated orientations but also crystallographic orientations. Then, they were enclosed in crystallized pale blue microcline (PBF) that crystallized later on (stage II). Crosshatched twins were formed during the successive temperature decrease (stage III). After this transition, the hydrothermal solution-feldspar interaction induced the formation of many $\mathrm{Ab}$ patches and a large number of micropores in the PBF part, resulting in the formation of the WF part (stage IV). This change might have been promoted by solution redeposition (Waldron et al., 1993); hence, even if preexisting exsolution perthites had formed, they would have been completely modified. This reaction caused the compositional reorganization of the perthite components with composition very close to the composition of the end members (albitization and $\mathrm{K}$-feldspathization). The change might have been promoted by the metasomatically moving albite from the outside (Fig. 10). The twin patterns became blurred at this stage. Further, the feldspar-solution interaction induced more extensive local changes in the WF part (stage V), which increased the turbidity.

From the compositional pair $\mathrm{Or}_{94-96}$ and $\mathrm{Ab}_{99}$ of the microperthites (Table 1) plotted on the Ab-Or binary phase diagram (Brown and Parsons, 1989), both the microcline crystallization and albitization in the present amazonitic alkali feldspar are estimated to have occurred around $200{ }^{\circ} \mathrm{C}$. The precise crystallization temperature of $\mathrm{Ab}$ laths could not be found out, because their original composition is unknown. Nevertheless, very low-temperature reactions occurred extensively in the pegmatite environment around $200{ }^{\circ} \mathrm{C}$, which is consistent with the results of other studies (Černý et al., 1984; London, 1996, 2005; Kohno et al., 2008). Such very low-temperature albitization and $\mathrm{K}$-feldspathization have been also found to occur in alkali feldspars from syenites (Nakano et al., 1997; Nakano, 1998) and granites (Lee and Parsons, 1997; Hashimoto et al., 2005).

\section{Geological implication of amazonitic feldspar from the Tanakami pegmatite}

The occurrence of amazonite-bearing pegmatites is restricted to two different geological locations (Martin and De Vito, 2005; Martin et al., 2008). Martin et al. (2008) 
stressed that such plumbean $\mathrm{K}$-feldspar is found in two distinct contexts: (1) NYF-type granitic pegmatites and related intrusive products of anorogenic magmatism, emplaced during periods of tectonic quiescence and distension of the crust, and (2) granite pegmatites developed in metamorphosed massive sulfide deposits, such as at Broken Hill, Australia. In the former, the presence of amazonitic $\mathrm{K}$-feldspar indicates the addition of $\mathrm{Pb}, \mathrm{U}, \mathrm{Th}$, and alkalis to the source prior to anatexis during the period of distension after a major orogenic disturbance. This process is closely related to anorogenic A-type granite magmatism (Martin et al., 2008). It is not clear at present whether the Tanakami pegmatite belongs to the abovementioned NYF-type, but it is obvious that it was formed by magmatism at the margin of the Asian Continent at the end of the Cretaceous period before the extension forming the Japan Sea (Kutsukake, 1993). The occurrence of amazonitic alkali feldspars in Japan suggests that amazonites or amazonitic alkali feldspars may occur widely in other places or regions where they have been not found yet.

\section{ACKNOWLEDGMENTS}

We thank late Mrs. U. Kobayashi for providing the amazonitic feldspar sample, Prof. emeritus M. Akizuki for his discussion about the origin of the microtextures, Mr. M. Ohkuma for his assistance to obtain FT-IR data, Mr. T. Kohno and Miss A. Masumori for their assistance in color measurements and Mr. H. Tsutsumi for his assistance in preparing thin sections of the sample. We also thank two anonymous referees for their constructive reviews, and Dr. N. Shimobayashi as the associate editor for his editorial handling, and Dr. M. Enami as the editor for his editorial checks of the manuscript, respectively.

\section{REFERENCES}

Bence, R.A. and Albee, A.L. (1963) Empirical correction factors for the electron microanalysis of silicates and oxides. Journal of Geology, 76, 382-403.

Brown, W.L. and Parsons, I. (1989) Alkali feldspars: ordering rates phase transformations and behaviour diagrams for igneous rocks. Mineralogical Magazine, 53, 25-42.

Brown, W.L. and Parsons, I. (1994) Feldspars in igneous rocks. In Feldspars and their reactions (Parsons, I. Ed.). pp. 650, NATO ASI Series C 421, Kluwer Academic Publishers, Dordrecht, 449-499.

Cech, F., Misar, Z. and Povondra, P. (1971) A green lead-containing orthoclase. Tschermaks' Mineralogische Petrographische Mitteilungen, 15, 213-231.

Černý, P. (1993) Rare-element granite pegmatites Part I: Anatomy and internal evolution of pegmatite deposits. Geoscience Canada Reprint Series, 6, 29-47.
Černý, P. (1994) Evolution of feldspars in granitic pegmatites. In Feldspars and their reactions (Parsons, I. Ed.). pp. 650, NATO ASI Series C, 421, Kluwer Academic Publishers, Dordrecht, 501-540.

Černý, P. and Chapman, R. (1984) Paragenesis chemistry and structural state of adularia from granitic pegmatites. Bulletin de Minéralogie, 107, 369-384.

Černý, P., Smith, J.V., Mason, R.A. and Delaney, J.S. (1984) Geochemistry and petrology of feldspar crystallization in the Vezna pegmatite, Czechoslovakia. The Canadian Mineralogist, 22, 631-651.

Collaborative research group for the granites around Lake Biwa (2000) Granitic masses around Lake Biwa Part 5: The Tanakami Granite pluton. Earth Science (Chikyu Kagaku), 54, 380-392 (in Japanese with English abstract).

Dana, E.S. and Ford, W.E. (1959) A Textbook of Mineralogy, $4^{\text {th }}$ ed. pp. 851, Modern Asia Edition, John Wiley and Sons, New York and Charles E Tuttle Company, Tokyo.

Deer, W.A., Howie, R.A. and Zussman, J. (2001) Rock-Forming Minerals Vol. 4A, Framework Silicates: Feldspars, $2^{\text {nd }}$ ed. pp. 972, The Geological Society, London.

Foord, E.E. and Martin, R.F. (1979) Amazonite from the Pikes Peak batholith. Mineralogical Record, 10, 373-384.

Goldsmith, J.R. and Laves, F. (1954) The microcline-sanidine stability relations. Geochimica et Cosmochimica Acta, 5, $1-19$.

Hashimoto, K., Akai, J. and Nakano, S. (2005) Microtextures of alkali feldspar in the Tanakami Granite southwest Japan and their formation processes. Japanese Magazine of Mineralogical and Petrological Science, 34, 1-14 (in Japanese with English abstract).

Hofmeister, A.M. and Rossman, G.R. (1983) Color in feldspars. In Feldspar mineralogy, $2^{\text {nd }}$ ed.(Ribbe, P.H. Ed.). pp. 362, Reviews in Mineralogy 2, Mineralogical Society of America, Washington, 271-280.

Hofmeister, A.M. and Rossman, G.R. (1985) A spectroscopic study of irradiation coloring of amazonite: structurally hydrous $\mathrm{Pb}$-bearing feldspar. American Mineralogist, 70, 794804.

Hofmeister, A.M. and Rossman, G.R. (1986) A spectroscopic study of blue radiation coloring in plagioclase. American Mineralogist, 71, 95-98.

Ishihara, S. (1977) The magnetite-series and ilmenite-series granitic rocks. Mining Geology, 27, 293-305.

Ishihara, S., Nakano, S. and Terashima, S. (2005) Chemical characteristics of the Tanakami Granite Kinki district - particularly important role of the radioactive and REE components. Bulletin of Geological Survey of Japan, 56, 93-98 (in Japanese with English abstract).

Kobayashi, S. (1989) Amazonite from Kurohira, Kofu City, Yamanashi Prefecture. Chigaku Kenkyu, 38, 193-198 (in Japanese).

Kohno, T., Nakano, S. and Shimobayashi, N. (2008) Color mantle-zoning of alkali feldspar from small pegmatites in the Tanakami Granite pluton, Shiga Prefecture, southwest Japan. Journal of Geological Society of Japan, 114, 435-446 (in Japanese with English abstract).

Kutsukake, T. (1993) An initial continental-margin plutonism Cretaceous Older Ryoke granitoids, southwest Japan. Geological Magazine, 130, 14-28.

Lee, M.R., Waldron, K.A. and Parsons, I. (1995) Exsolution and alteration microtextures in alkali feldspar phenocrysts from 
the Shap granite. Mineralogical Magazine, 59, 63-78.

Lee, M.R. and Parsons, I. (1997) Dislocation formation and albitization in alkali feldspar from the Shap granite. American Mineralogist, 82, 557-570.

London, D. (1996) Granitic pegmatites. Transactions of Royal Society of Edinburgh, Earth Science, 87, 305-319.

London, D. (2005) Granitic pegmatites: an assessment of current concepts and directions for the future. Lithos, 80, 281-303.

Martin, R.F. and De Vito, C. (2005) The patterns of enrichment in felsic pegmatites ultimately depend on tectonic setting. The Canadian Mineralogist, 43, 2027-2048.

Martin, R.F., De Vito, C. and Pezzotta, F. (2008) Why is amazonitic K-feldspar an earmark of NYF-type granite pegmatites? Clues from hybrid pegmatites in Madagascar. American Mineralogist, 93, 263-269.

Matsubara, S. (2003) Minerals in Japan. Field best encyclopedia, 15. pp. 260, Gakken (in Japanese).

Murakami, H., Takashima, I., Nishida, N., Shimoda, S. and Matsubara, S. (2000) Solubility and behavior of lead in green orthoclase (amazonite) from Broken Hill, New South Wales, Australia. Journal of Mineralogy, Petrology and Economic Geology, 95, 71-84.

Nagashima, K., Harada, K. and Honda, M. (1975) A new mineral masutomilite from Mt Tanakami, Otsu City, Shiga Prefecture. Chigaku Kenkyu, 26, 319-324 (in Japanese).

Nakano, S. (1997) Calcium distribution in a microperthite from the Nango pegmatite, Otsu city, Japan. Earth Science (Chikyu Kagaku), 51, 51-59.

Nakano, S. (1998) Calcium distribution patterns in alkali feldspar in a quartz syenite from Oki-Dozen, southwest Japan. Mineralogy and Petrology, 63, 35-48.

Nakano, S., Hosokawa, E. and Akai, J. (1997) Calcium distribution in alkali feldspar of a quartz syenite from Cape Ashizuri, southwest Japan. Mineralogical Journal, 19, 75-86.

Nakano, S., Makino, K. and Eriguchi, T. (2001) Microtexture and water content of alkali feldspar by Fourier-transform infrared microspectroscopy. Mineralogical Magazine, 63, 675-683.

Nakano, S. and Harayama, S. (2003) Geology of the Minakuchi district: Chapter 4 Late Cretaceous igneous rocks. Quadrangle series 1:50000, Geological Survey of Japan AIST, 12-40.

Nakano, S., Akai, J. and Shimobayashi, N. (2005) Contrasting $\mathrm{Fe}-\mathrm{Ca}$ distributions and related microtextures in syenite alkali feldspar from the Patagonian Andes, Chile. Mineralogical Magazine, 69, 523-537.
Ostrooumov, M. and Banerjee, A. (2005) Typomorphic features of amazonitic $\mathrm{K}$-feldspar from the Keivy granitic pegmatite (Kola Peninsula Russia). Schweizerische Mineralogische und Petrologische Mitteilungen, 85, 89-102.

Parsons, I. (1978) Feldspars and cooling plutons. Mineralogical Magazine, 42, 1-12.

Parsons, I. and Brown, W.L. (1984) Feldspars and the thermal history of igneous rocks. In Feldspars and Feldspathoids(Brown, W.L. Ed.). NATO Science Series C, 137, 317-371.

Pivec, E., Ševčik, J. and Ulrych, J. (1981) Amazonite from the alkali granite of the Avdar Massif Mongolia. TMPM Tschermaks Mineralogische und Petrographische Mitteilungen, 28, 277-283.

Smith, J.V. and Brown, W.L. (1988) Feldspar Minerals 1(2 $2^{\text {nd }}$ revised and expanded edition). pp. 828, Springer-Verlag, Berlin Heidelberg.

Stevenson, R.K. and Martin, R.F. (1986) Implications of the presence of amazonite in the Broken Hill and Geco metamorphosed sulfide deposits. The Canadian Mineralogist, 24, 729745.

Stevenson, R.K. and Martin, R.F. (1988) Amazonitic K-feldspar in granodiorite at Portman Lake northwest territories: indications of low $\mathrm{f}\left(\mathrm{O}_{2}\right)$ low $\mathrm{f}\left(\mathrm{S}_{2}\right)$ and rapid uplift. The Canadian Mineralogist, 26, 1037-1048.

Tsuji, K. and Kitahara, T. (1979) On minerals and ore deposits in Shiga Prefecture. In Land and life in Shiga, Foundation of nature conservation in Shiga Prefecture, 479-541.

Waldron, K., Parsons, I. and Brown, W.L. (1993) Solution-redeposition and the orthoclase-microcline transformation: evidence from granulites and relevance to ${ }^{18} \mathrm{O}$ exchange. Mineralogical Magazine, 57, 687-695.

Walker, F.D.L., Lee, M.R. and Parsons, I. (1995) Micropores and micropermeable texture in alkali feldspars: geochemical and geophysical implications. Mineralogical Magazine, 59, 505534.

Worden, R.H., Walker, F.D.L., Parsons, I. and Brown, W.L. (1990): Development of microporosity diffusion channels and deuteric coarsening in perthitic alkali feldspar. Contributions to Mineralogy and Petrology, 104, 507-515.

Manuscript received March 1, 2009

Manuscript accepted October 9, 2009

Published online February 2, 2010

Manuscript handled by Norimasa Shimobayashi 